\title{
STUDI TENTANG TINDAK PIDANA PELACURAN DI KOTA MAKASSAR
}

\author{
Syaparuddin \\ STKIP Muhammadiyah Enrekang
}

\begin{abstract}
The study aims at discovering (1) the factors which influence the prostitution in Makassar, (2) the forms of prostitution in Makassar, (3) the efforts of the local government in handling the prostitution the prostitution in Makassar. The study is a descriptive qualitative researach. Samples were obtained by conducting purposive sampling technique. Data of the study were collected through interview and documentation. Data were analyzed by employing qualitative analysis.

The results of the study reveal that (1) the factors which influence the prostitution in Makassar are weaker social control, increasing tollerance towards prostitution and infidelity, and poverty in terms of the needs are greater than the income; (2) the forms of prostitution in Makassar are street prostitutes, calling prostitutes, and brothel prostitutes; (3) the efforts of the local goveniment in handling the prostitution the prostitution in Makassar are refinement laws concerning prohibition or regulation of prostitution, intensification of religious education and spirituality to strengthen the faith of the religious values and moral norms, increasing the activities such as sports and recreation to make them busy to channel excess energy, expanding employment for women based on their talents to provide sufficient salary to fulfill their needs, providing sex education and the comprehension on values of marriage in family, forming coordination team consisted of several institutions and involving local community in preventing prostitution, foreclosuring books, magazines, films, and other media porn images which stimulate sex desire.
\end{abstract}

Keywords: Crime, Prostitution, Violation

\begin{abstract}
Abstrak
Penelitian ini bertujuan untuk memecahkan problem: (1) Faktor-faktor apakah yang berperan terhadap pelacuran di Kota Makassar (2) Bagaimanakah bentuk kejahatan pelacuran yang terjadi di Kota Makassar (3) Upaya apakah yang dilakukan oleh pemerintah setempat dalam menanggulangi pelacuran di Kota Makassar. Peneltian ini bersifat deskriktif. Pengambilan sample dilakukan secara Purposif. Pengumpulan data dilakukan melalui wawancara dan dokumentasi . Data dianalisis dengan menggunakan analisis kualitatif.

Hasil penelitian menunjukkan bahwa, Faktor yang berperan terhadap Pelacuran dikota makassar yaitu tingkat pendidikan pelacur yang sangat rendah, usia, serta faktor kemiskinan, dalam arti kebutuhan jauh lebih besar dari penghasilan, Bentuk kejahatan pelacuran di kota Makassar, yaitu, pelacur jalanan, pelacur panggilan dan pelacur bordil.

Upaya pemerintah antara lain, pembinaan yang berkesinambungan dalam arti bahwa ketika seorang pelacur telah direhabilitasi ke pihak keluarga, maka pihak pemerintah hendaknya pembinaan paling tidak contol tentang kondisi selanjutnya selain itu Penyempurnaan undang-undang tentang larangan atau pengaturan penyelenggaraan pelacuran, Intensifikasi pendidikan keagamaan dan
\end{abstract}


kerohanian untuk menginsafkan kembali dan memperkuat iman terhadap nilai religius serta norma ke. Peningkatan kegiatan seperti olahraga dan rekreasi, agar mendapatkan kesibukan sehingga mereka dapat menyalurkan kelebihan energi. Memperluas lapangan kerja bagi kaum wanita disesuaikan dengan kodratnya dan bakatnya, serta memberikan gaji yang memadahi dan dapat untuk membiayai kebutuhan hidup.

Kata kunci: Tindak Pidana, Pelacuran, Pelanggaran

\section{Pendahuluan}

Masalah kriminalitas adalah masalah manusia yang berupa suatu kenyataan sosial. yang sebab musababnya kerap kali kurang dipahami karena tidak melihat masalahnya menurut proporsi yang sebenarnya secara dimensional. Perkembangan peningkatan dan penurunan kualitas maupun kuantitas kriminalitas, baik yang ada di perkotaan maupun pedesaan adalah relatif dan interaktif sebab musababnya. Perkembangan di dalam dan di luar manusia tertentu, mempengaruhi kecenderungan dan kemampuannya untuk melakukan perilaku kriminal. Selanjutnya manusia tersebut mempengaruhi lebih lanjut manusia di sekitarnya serta lingkungannya dalam usaha memenuhi keperluan fisik, mental dan sosial secara positif maupun negatif. Setiap masyarakat pasti akan menghadapi masalah-masalah sosial, oleh karena terjadinya masalah sosial pribadi manusia maupun tingkah laku kelompok.

Suatu masalah merupakan problem sosial. apabila mempunyai akibat negatif dalam pergaulan hidup di masyarakat. Akibat yang negatif tersebut adalah suatu keadaan yang meresahkan warga masyarakat, sehingga pola-pola interaksi serta kelancaran proses interaksi menjadi sangat terganggu. Suatu akibat negatif semakin besar pengaruhnya, apabila hal itu tidak diatasi secara tuntas. Diharapkan dalam mengatasi problem baru yang semula sama sekali tidak diperhitungkan.Salah satu di antara pelacuran yang ada di dalam masyarakat di Kota Makassar Provinsi Sulawesi Selatan yang merupakan suatu tempat di mana germo mendirikan rumah-rumah bordir untuk para pelacur agar memudahkan melakukan praktek pelacuran sehingga para pelacur di Kota Makassar Provinsi Sulawesi Selatan tersebut semakin lama cenderung semakin meningkat dari pada menurun,

Pelacuran, berlangsung karena bebagai kondisi social yang tidak terelakkan sehingga masayarakat disekitar temapt pelacuran juga sulit untuk membedakan siapa dalang dan wayang dari pelacuran yang terjadi di kota makassar, untuk memahaminya perlu didekati secara manusiawi. Betapapun pelacuran yang terjadi di kota makssar harus ditanggulangi karena dapat menimbulkan berbagai akibat yang membahayakan kehidupan masyarakat, seperti timbulnya berbagai kriminalitas dan penyakit kelamin yang dapat dengan mudah ditularkan kepada anak dan isteri si penderita apalagi kota Makassar adalah kota niaga dan tempat belabuhnya kapal besar dari berbagai daerah bahkan dari luar negeripun Oleh karena itu penyakit kelamin mempengaruhi kesejahteraan sebagian anggota masyarakat Kota Makassar karena penyakit kelamin 
mengancam keselamatan, ketentraman dan kemakmuran baik jasmani maupun rohani di dalam kehidupan bersama.

$$
\text { pelacuran bisa terjadi }
$$

disebabkan oleh faktor Kemiskinan, dalam hal ini karena kehidupan ekonomi yang semakin meningkat mengakibatkan kebutuhan semakin meningkat pula sementara lapangan pekerjaan sangat terbatas dan sumberdaya yang dibutuhkan adalah sumberdaya yang potensial dalam segala bidang, baik di bidang akadenik maupun dalam kreatifitas. Selain itu pelacuran bisa dipicu karena ketidaktahuan sipelaku dan pengaruh dari teman atau kerabat yang mengatahui kondisi dari orang yang akan diajak dan merupakan mediator dalam memfasilitasi ajakan tersebut sesuai permintaan pasar atau pesanan atau lebih mudah dikenal dengan istilah pelanggan.

Bentuk kejahatan yang bisa terjadi akibat pelacuran antara lain penganiayaan yang berawal dari ketidak tahuan akan pekerjaan yang dijanjikan dan terjadi perlawanan , dan seseorang yang terjerumus dalam lembah pelacuran kerap mendapatkan penipuan dalam arti upah yang yang dijanjikan tidak sesuai dengan apa yang mereka terima, dan yang lazim terjadi adalah pelacuran dalam bentuk traffikking yang tanp sepengtetahuan sipelacur mereka telah dijual dengan upah yang sangat besar dan ditempatkan di tempat tertentu yang tidak mudah diketahui oleh keluarg sipelacur bahkan yng lebih tragis pelacuran bisa mengarah padah pembunuhan sebagi akibat darai perbuatan yang tidak ingin ketahuan dan akhirnya harus menghilangkan jejak dengan melakukakn pembunuhan.

Dalam menanggulangi pelacuran yang terjadi di kota makassar diperlukan suatu aturan yang jelas tentang isin operasional dari tempattempat pelacur melakukan kegiatannya pelacurannya dan selain itu diperlukan suatu bentuk kerjasama antara lembaga-lemabaga yang ada dalam wilayah tersebut dengan tetap mengedepankan budaya daerah yang sangat tabu terhadap pekerjaan yang asusila dan merusak masa depan bangsa.

Sebagaimana halnya dalam Islam, ajaran-ajaran agama lain pun melarang pelacuran. Oleh karena itu pelacuran merupakan masalah yang harus ditanggulangi karena sangat bertentangan dengan moral Islam dan agama lainnya dan pelacuran itu sndiri merebak dipusat-pusat kota seperti kota makassar dimana orientasi pemikiran sebagian masyarakat banyak mengarah pada pusat perkotaan untuk mendapatkan lapangan pekerjaan tanpa memperhatikan segala implikasi yang ditimbulkan termasuk kebijakan pemerintah dalam menerbitkan izin yang berkiblat pada tempat hiburan atau sejenisnya, selain itu peran penegak hukum serta pihak pihak yang terkait seperti tokoh agama, tokoh masyarakat, pemuda dan akademisi juga organisasi kemasyarakatan lainnya serta yang tak kalah pentingnya dan paling berperan dalam peningkatan pelacuran adalah pihak pengelola hotel sangat menentukan bagaimana pelacuran di perkotaan khususnya di kota Makassar.

\section{Tinjauan Pustaka. 2.1 Konsep Pelacuran}


Pelacuran sebuah nama yang diberikan untuk suatu perbuatan yang di dalamnya terlihat beberapa orang dalam suatu peristiwa. Kata pelacuran identik dengan kata asing prostitusi. Berasal dari bahasa latin "prostitue" yang dapat diartikan sebagai perilaku yang terang terangan menyerahkan diri untuk melakukan hubungan seksual.

\subsection{Lokasi Pelacuran}

Tempat pelacuran merupakan hal sangat menjijikkan bagi sebagian kalangan bahkan orang perorang menilai tempat berlangsungnya perbuatn mesum bagi para pelacur menjauhkan diri dari dari keberkahan dan dari berbagai sudut pandang bahwa perbuatn tersebut akan berdampak kesehatan dan lingkungan dan masa depan putra putri yang berdiam de lokasi dimana kegiatan atau aktifitas pelacuran itu terjadi. Pelacuran yang terpusat pada suatu tempat akan lebih mudah dilakukan pengawasan dan kontrol oleh pemerintah dalam berbagai bidang karena tidak tersebar dan tidak sulit dalam penjejakannya sehingga dampak yang ditimbulkan serta pencegahan terhadap dampak yang akan dtimbulkan akan lebih diminimalisir pelaksanaannya. Sebagai perbandingan dlam menentu.

Perbandingan dalam menentukan kemudahan tersebut berikut penulis menguraikan berbagai hal tentang lokalisasi seperti yang dikemukakan oleh : A.S. Alam (1984 : 24) memberikan pengertian sebagai berikut :

"Lokalisasi adalah tempat di mana terpusatnya sejumlah rumah bordil. Menunjukkan tempat pelacuran ini the red light district) yang memberikan izin kepada germo untuk mendirikan rumah bordil.Pelacuran di rumahrumah bordil sering memperlihatkan ciri tersendiri bila dibandingkan dengan bentuk pelacuran lainnya. Pelacuran dalam suatu kompleks terang-terangan dan bila dilihat sejumlah pembayaran yang diberikan kepada wanita, maka dapat diketahui bahwa pelacuran semacam ini dapat dikategorikan dalam kelas rendah.

\subsection{Pengertian Germo}

Germo atau baktau yang sehari-harinya banyak disebut dengan "mammie", "tante" atau "bos" adalah orang yang mata pencahariannya baik sambilan atau sepenuhnya, mengadakan atau turut serta mengadakan, membiayai, menyewakan, membuka dan memimpin serta mengatur tempat pelacuran. Untuk pekerjaan ini germo mengambil sebagian besar dari hasil yang diperoleh pelacur dari langganannya.

Untuk disebut sebagai germo menurut Pasal 296 KUHPidana. Andi Hamzah (1992: 119) menulis sebagai berikut :

"Barangsiapa dengan sengaja menyebabkan atau memudahkan perbuatan cabul dengan orang lain dan menjadikannya sebagai pencahariannya atau kebiasaan diancam dengan pidana penjara paling lama satu tahun empat bulan atau pidana denda paling banyak lima belas ribu rupiah". Ketentuan dalam Pasal 296 


\begin{abstract}
KUHPidana tidak hanya melarang dipermudahnya perbuatan-perbuatan

melanggar kesusilaan yang bersifat umum di tempattempat pelacuran, melainkan juga perbuatan mempermudah dilakukannya perbuatanperbuatan melanggar kesusilaan yang tidak bersifat umum, yang dilakukan sebagai mata pencaharian ataupun sebagai kebiasaan.
\end{abstract}

\subsection{Pengertian Pelacuran}

Praktek pelacuran dalam arti modus operandi pada pelacur dalam mendapatkan tamu atau langganannya dilakukan dengan berbagai cara, demikian juga tempat untuk meladeni tamunya sangat ditentukan oleh bentuk dan type pelacuran. Ada yang melakukannya di tempat-tempat terbuka, seperti di lapangan atau di bawah pohon yang gelap dan sepi, ada pula yang melakukan di gubuk-gubuk liar atau di tenda-tenda darurat yang sengaja disediakan untuk hal itu. Namun ada pula yang melakukan di rumahrumah atau di hotel-hotel yang bertaraf Internasional. Secara garis besarnya dapat disebutkan bentukbentuk dan tipe pelacuran yang banyak terdapat di masyarakat sebagai berikut :

1. Pelacuran Jalanan

Pelacuran jalanan adalah bentuk pelacuran yang sangat menyolok, karena pelacur akan bermunculan pada saat malam di tempat-tempat tertentu. Mereka menunggu tamu dengan berbagai cara, ada yang sengaja di tempat remang-remang, duduk di atas becak, bahkan ada yang sengaja berdiri sendirian di pinggir jalan sambil merokok untuk mencari perhatian pada orang-orang yang lewat. Mereka dapat dikenali dengan mudah dari tingkah laku yang diperlihatkannya, memakai alat kosmetik sangat berlebihan seperti memakai lipstik yang menyolok, bedak yang tebal dan memakai model yang sengaja menonjolkan bagian-bagian tubuh tertentu dengan warna pakaian yang sangat kontras.

Pelacuran jalanan dapat digolongkan ke dalam kategori kelas rendah dengan tarif antara $\mathrm{Rp}$. 50.000 sampai Rp. 100.000.- sebagai langganan mereka umumnya berasal dari buruh-buruh pabrik, buruhburuh pelabuhan, pedagang kecil tukang becak dan lain sebagainya yang berpenghasiIan rendah. Namun tidak menutup kemungkinan adanya remaja-remaja dari golongan berada yang berkunjung ke tempat itu. hanya sekedar ingin mencoba melepaskan dorongan sexualnya. Dari penghasilan para pelacur yang sangat minim sangat mempengaruhi taraf kehidupan dan pemeliharaan kesehatan mereka. Sangat jarang dan bahkan tidak pernah sama sekali memperoleh pemeriksaan dokter untuk mengontrol adanya kemungkinan mereka menderita penyakit kelamin. Sebagai konsekuensi logis dari keadaan tersebut, menurut A.S. Alam (1984: 55) menjelaskan sebagai berikut :

"Tidaklah mengherankan bila seseorang yang telah melakukan hubungan kelamin dengan mereka akan terkena penyakit kelamin seperti misalnya spilis. Mengingat penyakit kelamin adalah penyakit menular, para tamu yang telah terserang penyakit 
itu akan mudah memindahkannya pula kepada keluarganya".

Jadi akibat nyata yang menyangkut kesehatan itu bahwa pelacuran merupakan salah satu sumber penyakit kelamin. Penyakit kelamin yang dapat terjangkit dan menular umumnya adalah kencing nanah dan spilis, dan beberapa waktu yang lalu didengar adanya sejenis penyakit kelamin yang lebih ganas lagi yang dikenal dengan nama Vietnam Rose.

\section{Metode Penelitian}

\subsection{Lokasi dan Waktu Penelitian}

Adapun lokasi penelitian dalam penulisan ini adalah Kota Makassar sesuai dengan pertimbangan praktis "sehingga penulis memilihnya. Kota Makassar Provinsi Sulawesi Selatan yang telah memiliki lokalisasi yang terorganisir, sehingga penulis lebih mudah melakukan penelitian jika dibandingkan dengan keadaan pelacuran di Kabupaten/Kota lainnya yang masih terpencar-pencar letaknya.

\subsection{Populasi dan Sample}

Menurut Bambang Supranto (2003 : 23 populasi biasa diartikan sensus keseluruhan atau himpunan objek dengan ciri yang sama. Populasi dapat berupa himpunan orang, benda hidup atau mati, kasuskasus, waktu atau tempat dengan sifat dan ciri yang sama. Populasi yang dijadikan objek dalam penelitian ini adalah seluruh pekerja seks komersial yang tersebar di beberapa lokalisasi di Kota Makassar Populasi yang disebutkan di atas tidak mungkin dapat diteliti secara keseluruhan, oleh karena itu Peneliti menetapkan sampel yang akan dijadikan responden dan atau informan. Agar setiap populasi mempunyai peluang yang sama untuk dipilih sebagai sampel maka peneliti menggunakan teknik sampel acak (random sampling), yaitu populasi yang tidak dipilah-pilah melainkan disetarakan. Dasar pertimbangan adalah karena kapasitas dan kompetensinya cukup representatif.

Sampel adalah bagian dai populasi yang menjadi bagian yang akan diteliti ( Amiruddin;2003;96)

Untuk penentuan sampel terhadap informan yang akan diwawancarai digunakan teknik pengambilan sampel purposif (purposive sampling), yaitu sampel diambil secara sengaja atas kriteria atau pertimbangan tertentu. Berdasarkan uraian tersebut maka jumlah individu yang akan dijadikan sampel adalah sebanyak 30 orang.

\subsection{Jenis dan Sumber Data}

Dalam penelitian ini diperlukan dua jenis data yaitu data primer dan data sekunder sebagai berikut :

1. Data Primer adalah data yang diperoleh langsung dari beberapa daerah lokalisasi di Kota Makassar. Data ini diperlukan untuk mengetahui faktor-faktor yang mempengaruhi terjadinya pelacuran.

2. Data sekunder adalah data yang diperoleh tidak secara langsung, tetapi dengan mengkaji/menelaah bahanbahan hukum, hasil-hasil penelitian dan sumbersumber lainnya yang relevan dengan permasalahan yang diteliti. 


\subsection{Teknik Pengumpulan Data}

Data penelitian ini dikumpulkan dengan teknik :

1. Dokumentasi adalah bahan hukum berupa peraturanperaturan dan kaidah-kaidah yang didukung studi kepustakaan (Library research) yaitu penelusuran terhadap literatur sebagai sumber untuk menelaah berbagai teori yang relevan masalahnya dengan objek penelitian.

2. Penelitian lapangan (Field research) Penelitian ini dilakukan secara langsung terhadap objek yang akan diteliti dengan menggunakan teknik:

a. Wawancara / Interview yaitu mengadakan wawancara langsung dengan para pekerja seks komersial (PSK). Di samping itu mengadakan wawancara langsung terhadap para mucikari yang diolah secara kulaitatif dan kuantitatif bedasarkan data yang telah di peroleh

b. Pengamatan (Observasi) yaitu dengan mengadakan pengamatan langsung terhadap kegiatan yang dilakukan oleh para pekerja seks komersial (PSK) dan lelaki hidung belang.

\subsection{Analisi Data}

Dalam rangka penelitian
masalah pelacuran, peneliti
menggunakan metode pendekatan
deskriptif untuk mencoba
menganalisis gejala sosial dalam arti
yang luas dan berusaha mengkaji
yang mempunyai hubungan terhadap
pelacuran, yang mana pelacuran
merupakan sumber dari pola
kriminalitas.

Guna mengelola data yang telah dikumpulkan, akan digunakan teknik analisis data secara kualitatif maupun secara Analisis Kualitatif. Analisis mengenai gambaran umum dunia pelacuran dan ada tidaknya pemerasan terhadap pelacur dilakukan dengan cara kualitatif. Didalam penggunaan metode, kualitatif, peneliti mempunyai kebebasan yang lebih luas untuk mengadakan interpretasi- interpretasi dari data yang telah dikumpulkan dan kemudian menarik kesimpulankesimpulan.

\section{Hasil Penelitian dan}

\section{Pembahasan.}

\subsection{Gambaran Umum.}

Lokasi pelacuran di Kota Makassar terdapat di empat lokasi yaitu , kecamatan tamalate, Kecamatan Wajo, kec ujung tanah dan kecamatan Biringkanaya yang posisi letak dan atau tempat para pelacur melakukan aktifitas menyebar di setiap kecamatan yang tersebut di atas, namum yang dominan dilakukan oleh pelacur adalah di wisma seperti wisma lydiana jln pelita dan wisma atau penginapan lainnya yang ada kota makassar pelu penulis ungkapkan disini bahwa da i sekian rumah-umah bodil yang ditempati oleh pelacur tersebut Pelacuran di lokasi tersebut dapat di golongkan rumah-rumah bordil. Pelacuran di rumah-rumah bordil memperlihatkan ciri tersendiri bila dibandingkan dengan bentuk pelacuran lainnya. Di Indonesia pelacuran bordil umumnya dilakukan secara terang-terangan di tengahtengah masyarakat.

Kota Makassar bila dilihat dari tahun ke tahun mengalami 
perkembangan yang cukup pesat, baik dari sektor perindustrian maupun di sektor perkebunannya. Dulunya lokasi pelacuran ini berada di pinggiran kota, tetapi karena tuntutan perumahan, sehingga kompleks pelacuran tersebut berada ditengah-tengah perumahan penduduk. Hal ini telah dirasakan sangat menganggu ketertiban umum. Oleh karena itu masalah ini perlu mendapat perhatian pemerintah setempat.

\subsection{Kegiatan di lokasi pelacuran Kota Makassar}

Selanjutnya menurut Hasan Bahwa Kegiatan pada lokasi pelacuran Kota Makassar terjadi antara jam 09.00 pagi sampai jam 23.00 malam. Walaupun ada peraturan yang dikeluarkan oleh pemerintah setempat bahwa pada jam 24.00 malam semua rumah bordil sudah harus menghentikan semua kegiatannya dan tidak lagi diperkenankan menerima tamu, hal ini dimaksudkan untuk mencegah terjadinya hal-hal yang tidak diinginkan karena lokasi pelacuran merupakan tempat rawan terjadinya kriminal, namun dalam kenyataannya peraturan ini sering dilanggar, banyak rumah-rumah bordil yang masih menerima tamu pada tengah malam bahkan ada tamu yang bermalam, baik dengan jalan melaporkannya kepada keamanan setempat maupun dengan jalan diamdiam, tetapi tentunya dengan sepengetahuan dan seizin germo sebagai penanggung jawab penuh. 4 . Jumlah tamu.

Jumlah tamu yang dilayani pelacur sehari bervariasi tergantung dari jumlah pengunjung, misalnya hari-hari lain sangat berbeda pada malam minggu, demikian juga jumlah pengunjung diakhir bulan terlihat agak kurang dibandingkan dengan minggu pertama pada setiap bulannya, dimana orang baru menerima gaji mereka.

dari petugas Dinas $\begin{array}{r}\text { Menurut data } \\ \text { Sosial }\end{array}$ mengatakan bahwa tidak kurang dari 300 orang laki-laki yang mengunjungi lokasi pelacuran setiap harinya. Tidak semua laki-laki yang berkunjung ke lokasi pelacuran akan melakukan hubungan kelamin dengan pelacur, sebagian dari mereka hanya menemani temannya dan pula hanya duduk minum minuman keras diruang tamu

Kadang-kadang ada pelacur yang meladeni tamunya sampai 8 orang dan ada juga yang hanya meladeni 1 atau 2 orang saja masingmasing tarif yang dibayar antara $\mathrm{Rp}$. 200.000,- sampai Rp. 300.000,-. Bila tamu akan bermalam dikenakan bayaran sekitar Rp. 150.000,- sampai Rp. 200.000,-.

4.3 Faktor yang Berperan tehadap Pelacuran di Kota Makassar.

1. Kehidupan Pelacur.

Dalam uraian ini akan diungkapkan hal-hal yang menyangkut kehidupan pelacur, sekaligus merupakan factor penyebab terjadinya pelacuran, baik sebelum maupun sesudah mereka terjun ke dunia pelacuran.

a. Tingkat usia pelacur

Berdasarkan hasil wawancara yang dilakukan di lokasi pelacuran di Kota Makassar diperoleh data sebagai berikut : Pelacur umur 17-22 tahun lebih dari $70 \%$ dan yang berumur 29 tahun keatas 
hanya lebih $2 \%$. Sebelumnya ada diantara mereka telah menjadi pelacur pada usia yang sangat muda, yakni sebelum mencapai 15 tahun, banyak diantara mereka telah menjadi pelacur ditempat lain sebelum pindah ke lokasi pelacuran di Kota Makassar. Factor usia bukan merupakan factor utama, ada hal lain yang menurut hemat penulis menjadi paktor penyebab pelacuran adalah tingginya aspirasi material dan dukungan budaya, meski peranan kemiskinan tidak dapat diabaikan, akan tetapi kondisi real dalam masyarakat tampak sebagai kegiatan sosial yang kadang harus dipolemikkan, di sisi lain masyarakat juga sabagian enggan untuk ikut campur padahal semestinya masalah tersebut bukan hanya tugas dari depertemen sosial dan depertemen tertentu melainkan adalah merupakan tugas semua lapisan masyarakat yang perlu dicermati karena bersifat universal, selanjutnya penulis berasumsi bahwa realita tentang pelacuran juga disebabkan oleh factor

1. Kontrol sosial masyarakat yang menjadi melemah

2. Toleransi terhadap pelacuran dan peselingkuhan semakin meningkat

3. Faktor kemiskinan, dalam arti kebutuhan jauh lebih besar dari penghasilan yang mengakibatkan

pelacur melakukan
berbagai macam cara
untuk mendapatkan
imbalan walau harus
dengan menjual diri.

4. Motif pelacur tidak hanya datang dari diri sipelacur sendiri, namun dapat terjadi dari beberapa kondisi yang akan diuraikan dengan berbagai data yakni, Umur, pendidikan, status perkawinan, dan sebagainya

4.4 Bentuk kejahatan pelacuran di kota Makassar Adapun Profesi pelacur dijalankan dengan kondisi sebagai berikut :

a. melakukan profesinya secara sadar dan suka rela, berdasarkan motifasi tertentu.

b. Dijebak dan dipaksa oleh germogermo yang terdiri dari penjahat, calo, anggota organissi gelap penjual wanita dan pengusaha bordil.

Sedangkan cirri-ciri dari pelacur adalah sebagai berikut :

a. bila yang mengawaki disebut pelacur, dan bila pria disebut gigolo.

b. Cantik (ganteng), rupawan, manis, atraktif menarik wajah dan tubuhnya, dapat merangsang selera seks lawan jenisnya.

c. Masih muda dibawah 30 tahun

d. Pakaian sangat menyolok, seksi, eksentrik untuk mensrik perhatian lawan jenisnya.

e. Mereka memperlihatkan penampilan lahiriah seperti : wajah, rambut, pakaian, alat kosmetik, parfum yang merangsang. 
f. Menggunakan teknis seksual yang mekanistis, cepat, tanpa emosi dan afeksi, tidak pernah mencapai organsme, sangat provokatif, dilakukan secara kasar.

g. Bersifat mobil sering berpindahpindah dari kota satu ke kota lainnya.

h. Biasanya berasal dari strata ekonomi dan social rendah, tidak mempunyai ketrampilan khusus, berpendidikan rendah. Sedangkan pelacur kelas tinggi biasanya berpendidikan tinggi, beroperasi secara amateur atau professional.

Fungsi pelacur yaitu menjadi sumber eksploitasi bagi kelompokkelompok tertentu, khususnya bagi mereka yang memberikan partisipasi. Pada umumnya masyarakat menolak adanya pelacuran, tetapi dalam kenyataannya mereka tidak bisa mengelak dan harus menerimanya . kedudkukan social pelacur sangat rendah, tugasnya memberikan pelayanan seks kepada kaum pria, namun demikian ada beberapa fungsi yang tergolong positif sifatnya, bagi masyarakat. Fungsi yang dimaksud dapat dijadikan katup pengaman yang secara jujur diakui, sebab dapat dijadikan sebagai berikut :

a. Sumber pelancar dalam dunia business.

b. Sumber ksenangan dari kaum yang harus berpisah dari istrinya.

c. Sumber hiburan individu atau kelompok

d. Sumber pelayanan dan hiburan bagi orang cacat (misalnya pria yang wajahnya buruk, pincang, abnormal seksualnya dan para penjahat).
Dalam menjalankan fungsinya para pelacur tersebut berlatar belakang menderita lemah mental, penghayal dan psikopat, atau dengan kata lain rohaninya tidak sempurna. Oleh sebab itu kehidupannya pada umumnya dihiasi dengan kemewahan semu berupa pakaian yang gemerlapan, makanan yang lezat dan berlimpah, bergantiganti partner, tanpa ikatan, tanpa tanggung jawab.Sebelum penulis menguraikan lebih jauh tentang akibat terjadinya pelacuran akan dijelaskan tentang sebagian contoh dari jenis pelacuran Panggilan, pelacuran Bordil dan pelacur jalanan dengan kasus beberapa orang pelacuran yang motif tidak jauh berbeda antara pelacur jalanan, pelacur panggilan dan pelacu bordil, hanya pelaku dan waktu serta jalan aktifitas yang brebeda, yang saat penulis lakkukan wawancra mereka enggan untuk mengatakan yang sebenarnya tapi dengan alasan untuk penelitian akhirnya wanita wanita tersebut mengisahkan perjalanan kelamnya yang terangkum dari hasil wawancara pada tanggal 1 juni 2013. Di jalan nusantara. Kota Makassar 1.Pelacuran panggilan, Kasus yang dialami tina, asal Sulawesi tengah Palu, Umur, 37 tahun, pendidikan SD, berdasarkan hasil wawancara penulis dengan tina mereka menuturkan sebagai berikut:

"Berawal dari rasa sakit hati saya terhadap sang suami yang karena alasan mencari nafkah ternyata dalam jangka beberapa bulan kemudian malah bukan pekerjaan dan hasil pekerjaan yang diperoleh melainkan berita tentang perselingkuhannya dengan seorang rekan kerja suami saya, hal tersebut 
saya terima dari laporan yang disampaikan oleh rekan kerjanya yang bernama Dedi yang kemudian disusul oleh pengakuan suami saya yang bernama yusuf, saya bagai disambar petir saat mendengar pengakuan itu karena saya harapkan jauh dari kenyataan, dengan memendam rasa sakit yang begitu pedih. Selanjutnya, dalam perjalanan hidup, saya bertemu seseorang teman bernama hasna , dia mengajak untuk menawarkan pekerjaan dan saya langsung mengiyakan , saat saya ditawari saya tidak berpikir panjang lebar saya langsung berangkat dan diantar kejalan Bali makassar untuk diperkenalkan pada seorang ibu yang sangat menor penampilannya yang oleh orang- disekitar tempat tersebut memanggilnya dengan nama "mami" , singkat perjalanan saya dijanji untuk mulai bekerja esok harinya dengan catatan satu sebelumnya harus rawat diri dulu, saya jadi kaget kenapa hanya untuk kerja harus dengan persiapan merawat diri, pekerjaan apa sebenarnya yang akan ditawarkan.

Ternyata apa yang dijanjikan si mami terbukti malah waktunya maju lebih cepat, saat itu saya di minta untuk mengganti baju yang telah disiapkan dan pakainan yang saya bawa dating tidak usah dibawa itu pesan mami, seseorang menjemput saya dengan alasan untuk bekerja sebagai kasir pasa sebuah swalayan yang cukup besar dengan iming-2iming gaji yang cukup lumayan, akhirnya sayapun dengan semangat yang tinggi berangkat dan ternyata setelah sampai di temapt tujuan saya bukannya bekerja tapi malah di kerjain, awalnya menolak dan memberontak tapi dengan bayaran yang saat itu diperlihatkan sejumlah 500 ribu akhirnya pasrah tambah lagi rasa sakit terhadap sang suami akhirnya pekerjaan itu saya geluti, setelah aktifitas itu selesai saya diantar pulang ke rumah si mami dan menunggu panggilan berikutnya, hasil yang saya terima saya simpan dan ternyata simami telah menerima uang kontrak sebelum saya berangkat jadi apa yang peroleh tidak terpotong lagi, itulah sekelumit tentang perjalanan saya, kenapa saya melkukan pekerjaan ini, sakit memang tapi apa yang harus saya lakukan semuanya sudah terlanjur.

Apa yang dialami tina sama persis kasus yang dialami oleh Masita dan Naharia yang masingmasing beralamat di Makassar dan pekkabata

Berikut penulis akan menguraikan sekilas tentang salah satu contoh Jenis pelacuran jalanan.

2. Pelacur jalanan, berdasarkan hasil penelitian yang penulis lakukan, jenis pelacuran yang terbanyak yang dijumpai di kota Makassar adalah pelacuran dalam bentuk pelacuran jalanan dengan motif yang berbeda, si Suryanti Rahman, alamat Makassar, j1 sudiang, umur 39 tahun, menggeluti pekerjaan sebagai pelacur dengan alasan ekonomi, yang mempunyai temngkal mangkal di jln nusantara dan mulai beraktifitas jam 21.00 hingga 03 dinihari, itupun tidak tetap tergantung cuaca, ungkapnya, saya mangkal di muka toko dan tempat hiburan malam jam 9 malam karena perjalan dari rumah saya ke tempat saya melakoni peerjaan ini 
memakan waktu 30 menit bahkan kadang sampai satu jam dengan menggunakan kendaraan angkutan umum, saya melakukan pekerjaan ini karena desakan ekonomi, dan tidak membutuhkan waktu yang terlalu banyak hanya dilakukan malam hari, lain lagi dengan kisah ratna, asal menado umur kurang lebih 50 tahun, bersuami 8 kali , anak sejumlah 18 orang dan telah menekuni pekerjaannya sebagai PSK (pelaku Seks Komersial) selama 20 Tahun, jenis pelcuran yang dilakoninyapun menurut pengakuan si ratna di lalui dijalani seluruhnya, bias pekacur jalanan, panggilan dan seali kali di rumah bordil, imbuhnya 3. Adapun jenis pelacuran bordil di kota Makassar, secara kasat mata memang tidak Nampak tapi setelah penulis melakukan penelitian langsung ternyata tampat panti pijat, dan hiburan malam dapat berorientasi sebagai rumah bordil yang dimanfaatkan oleh orang-orang tertentu untuk melampiaskan nafsu birahi yang tidak terkendali yang juga menurut hasil pengamatan penulis terpusat dijalan nusantara dan sebagian menyebar di tempat tempat hiburang lainnya di kota Makassar, berdasarkan pengakuan Ratna kendatipun dia hanya diperkenankan menerima tamu sampai jam 23.00 mengingat beban yang mereka harus tanggung kadang sampai pagi menerima orderan secara bergantian dengan tariff sekitar 100 ribu sampai 200 ribu bahkan kadang hanya 50 ribu, kemudian seperduanya diambil oleh germo, akunya.

\subsection{Akibat-akibat pelacuran}

Praktek-praktek pelacuran biasanya ditolak oleh masyarakat dengan cara mengutuk keras, serta memberikan hukuman yang berat bagi pelakunya. Namun demikian ada anggota masyarakat yang bersifat netral dengan sikap acuh dan masa bodoh. Disamping itu ada juga yang menerima dengan baik. Sikap menolak diungkapkan dengan rasa benci, jijik, ngeri, takut dll. Perasaan tersebut timbul karena prostitusi dapat mengakibatkan sebagai berikut:

a. Menimbulkan dan menyebarkan penyakit kelamin dan penyakit kulit. Penyakit kelamin tersebut adalah sipilis dan gonorrgoe. Keduanya dapat mengakibatkan penderitanya menjadi epilepsi, kelumpuhan, idiot psikotik yang berjangkit dalam diri pelakunya dan juga kepada keturunan.

b. Merusak sendi-sendi kehidupan keluarga, sehingga keluarga menjadi berantakan.

c. Memberi pengaruh demoralisasi kepada lingkungan, khususnya remaja dan anak-anak yang menginjak masa puber.

d. Berkorelasi dengan kriminalitas dan kecanduan minuman keras dan obat terlarang (narkoba).

e. Merusak sendi-sendi moral, susila, hukum dan agama.

f. Terjadinya eksploitasi manusia oleh manusia lain yang dilakukan oleh germo, pemeras dan centeng kepada pelacur. 
g. Menyebabkan terjadi disfungsi seksual antaralain : impotensi, anorgasme

\section{Kesimpulan}

Dari hasil penelitian yang dilaksanakan oleh penulis, maka yang menjadi kesimpulan adalah sebagai berikut :

1. Faktor yang berperan terhadap terjadinya pelacuan di kota Makassar yaitu Tingkat pendidikan pelacur yang sangat rendah, factor usia juga menjadi salah satu faktor namun bukan faktor utama, dukungan budaya dalam arti bahwa karena masyarakat kadang tabu menegur pelaku atau melarang karena takut kualat, selain itu factor kemiskinan dan control social masyarakat yang lemah serta toleransi tehadap pelacuran itu sendiri yang semakin meningkat.

2. Bentuk kejahatan pelacuran di kota Makassar yatu , Pelacuran panggilan, yang berarti setia menati pengunjung yang akan melakukan transaksi, kemudian pelacuran jalanan yakni pelacur mangkal dijalan dengan motif yang bebeda dan bentuk kejahatan pelacuan yang teakhir adalah pelacuran bordil, jenis atau bentuk pelacuran ini tidak bisa di lihat dari sisi tempatnya saja karena fungsinya dari label yang ada tidak berorientasi pada pelacuran melainkan lebih pada fungsi kesehatan, hiburan dan sebagainya, sepeti misalnya: panti Pijat dan .Tempat Hiburan malam

3. Upaya Penanggulangan Praktek Pelacuran di kota Makassar Pembinanan yang berkesinambungan, dalam arti bahwa ketika seorang pelacur telah direhabilitasi dan diserahkan kekeluarga pihak pemerintah hendaknya melanjutkan pembinaan paling tidak control tentang kondisi selanjutnya. Perencanaan program perlakukan kepada pelacur kurang mempehatikan peranan ahli psikoligi dan pendidikan.

Selain itu Usaha yang bersifat preventif diwujudkan dalam kegiatan-kegiatan untuk mencegah terjadinya pelacuran kegiatan yang dimaksud berupa :

a. Penyempurnaan undang-undang tentang larangan atau pengaturan penyelenggaraan pelacuran.

b. Intensifikasi pendidikan keagamaan dan kerohanian, untuk menginsafkan kembali dan memperkuat iman terhadap nilai religius serta norma kesusilaan.

c. Bagi anak puber dan remaja ditingkatkan kegiatan seperti olahraga dan rekreasi, agar mendapatkan kesibukan, sehingga mereka dapat menyalurkan kelebihan energi.

d. Memperluas lapangan kerja bagi kaum wanita disesuaikan dengan kodratnya dan bakatnya, serta memberikan gaji yang memadahi dan dapat untuk membiayai kebutuhan hidup.

\subsection{Saran}

Sehubungan dengan kesimpulan penelitian di atas, maka dengan demikian diajukan saan sebagai beikut :
1. Kiranya lembaga-lembaga pemerintah yang terkait dan masyarakat diberikan beban 
untuk mengusahakan dengan sungguh-sungguh sesuai dengan peranannya masing-masing untuk menanggulangi akses-akses negatif akibat pelacuran.

2. Peranan orang tua sangat menentukan dalam menanamkan moral dan pendidikan agama kepada anak gadisnya agar tidak mudah terjerumus ke dunia

\section{DAFTAR PUSTAKA}

Amiruddin,2003, Pengantar Metode penelitian hokum, Raja Gafindo Persada, Jakarta

Ilmar, A., Thalib, H. H., Badaru, H. B., \& Wahyuddin, M. A. Immigration Control of Abuse of Visa and Permit to Stay in Indonesia.

Awaluddin Hamid, 2012,Hak Asasi Manusia,

Politik,Hukum,Kemunafikan intenasional, Kompas media Nusantara, jakarta

Alam. A.S.. 1984. Pelacuran dan Pemerasan Studi Sosiologis Tentang Eksploitasi Manusia Oleh Manusia. Alumni. Bandung

Andi Hamzah, 1992. Asas-Asas Hukum Pidana, Rineka Cipta, Jakarta

----------, 1992. Kitab UndangUndang Hukum Pidana dan Kitab Undang-Undang Hukum Pidana, Rineka Cipta. Jakarta.

Pidana 2000, Hukum Acara
Grafika, Jakata
Atmasasmita Romli,1995, Capita
Selecta Hukum Pidana dan

pelacuran yang sangat bertentangan dengan agama.

3. Para penegak hukum hendaknya menjalankan secara tegas pasalpasal dalam KUHP yang menyangkut pelacuran untuk menekan semakin meluasnya pelacuran.

Kriminologi, Mandar maju, bandung.

Banger. W.A 1970. Pengantar Tentang Kriminologi. PT. Ghalia Indonesia.

Gosita. Arif. 1933. Masalah Korban Kejahatan Akademika. Pressindo, Jakarta

Hadsaami, Safi'e 1982. 1990 Hukum Pidana Indonesia. Sinar Baru, Bandung.

---------, 1990. Dasar-Dasar Hukum Pidana Indonesia. Sinar Baru. Bandung.

A Istiqlal Assaad, 2017. Hakikat

Sanksi Dalam Perspektif Hukum Pidana Indonesia Dan Hukum Pidana Islam (Studi Tentang Pidana Mati). Al-Ishlah : Jurnal Ilmiah Hukum, Fakultas Hukum Universitas Muslim Indonesia.

Moeljanto, 1987. Asas-Asas Hukum Pidana, Bina Aksara, Jakarta.

Nawawi Barda,2003, Capita Selecta Hukum Pidana,Citra aditia Bakti ,Bandung

Prodjodikoro. Wirjono. 1989. AsasAsas Hukum Pidana di Indonesia, LEPPEN UMI, Ujung Pandang.

Qamar, N., Badaru, B., \& Aswari, A. 2017. Local Wisdom Culture 
of Bugis-Makassar in Legal Perspective. In Proceeding 12th ADRI 2017 International

Multidisciplinary Conference and Call for Paper, Bogor, March 30-April 01, 2017 (p. 87).

Situmorong. $\quad$ Viktor. 1988.

Kedudukan Wanita di Mata Hukum. Penerbit Bina Aksara, Jakarta.

Sudarto. 1983. Hukum Pidana dan Perkembangan Masyarakat. Penerbit Sinar Baru, Bandung.

Sudiana, Nana. 1991. Tuntutan Penyusunan Karya Ilmiah. Makalah, Tesis, Tesis dan Disertasi. Sinar Baru, Bandung.

Sutrisno Hadi. 1984. Metodelogi Penelitian Research. Untuk Penulisan Paper. Tesis. Thesis, dan Disertasi. Fakultas Psikologi UGM. Jogyakarta.

Supranto,2003. Metode penelitian dan statistic, Pt Asdi Mahasatya, Jakarta

Sulistyowaty Irianto 2008. Perempuan dan Hukum menuju hukum yang berperspektif kesetaraan dan keadilan.,Yayasan Obor Indonesia DKI jaya.

Soedjono. D. 197 7. Pelacuran Di Tinjau Dari Segi Hukum Dan Kenyataan Dalam Masyarakat, T. Karya Nusantara, Bandung. ----. 1981. Dokrim-Dokrim Kriminologi. Alumni. Bandung.
Soekanto. Soerdjono. 1982. Suatu Tinjauan Sosiologi Hukum Terhadap Masalah-Masalah Sosial, Alumni. Bandung.

---------. 1982. Kriminologi Suatu Pengantar. Ghalia Indonesia. Jakarta.

1982. Pengantar Penelitian Hukum. Universitas Indonesia. Jakarta.

Soessilo, R. 1976. Kriminologi Pengetahuan Tentang SebabSebab Kejahatan, Politeia. Bogor.

1982. Kitab Undang-undang Hukum Pidana Serta Komentar-Komentar Lengkap Pasal Demi Pasal. Politeia. Bogor.

Sutrisno Hadi. 1984. Metodelogi Penelitian Research. Untuk Penulisan Paper. Tesis. Thesis, dan Disertasi. Fakultas Psikologi UGM. Jogyakarta.

Supranto,2003. Metode penelitian dan statistic, Pt Asdi Mahasatya, Jakarta

Widayanti. Ninik dkk.. 1987. Kejahatan Dalam Masyarakat Dan Pencegahannya. Bina Aksara. Jakarta.

Undang-undang

KUHP dan KUHAP 2005 , Redaksi Penerbit asa mandiri 